\title{
Lausannevirus Seroprevalence among Asymptomatic Young Adults
}

\author{
Linda Mueller $^{a}$ David Baud ${ }^{a, c}$ Claire Bertelli ${ }^{a, d}$ Gilbert Greub ${ }^{a, b}$ \\ anstitute of Microbiology and ${ }^{\mathrm{b}}$ Service of Infectious Disease, University Hospital Center and \\ University of Lausanne, 'Materno-Fetal and Obstetrics Research Unit, Department of Obstetrics and Gynaecology, \\ Maternity, University Hospital, and d SIB Swiss Institute of Bioinformatics, Lausanne, Switzerland
}

\section{Key Words}

Megavirales · Marseilleviridae · Lausannevirus .

Serology Prevalence Chlamydia $\cdot$ Immunofluorescence .

Cross-reactivity

\begin{abstract}
Objectives: The giant Lausannevirus was recently identified as a parasite of amoeba that replicates rapidly in these professional phagocytes. This study aimed at assessing Lausannevirus seroprevalence among asymptomatic young men in Switzerland and hopefully identifying possible sources of contact with this giant virus. Methods: The presence of anti-Lausannevirus antibodies was assessed in sera from 517 asymptomatic volunteers who filled a detailed questionnaire. The coreactivity between Lausannevirus and amoebaresisting bacteria was assessed. Results: Lausannevirus prevalence ranged from 1.74 to $2.51 \%$. Sporadic condom use or multiple sexual partners, although frequent (53.97 and $60.35 \%$, respectively), were not associated with anti-Lausannevirus antibodies. On the contrary, frequent outdoor sport practice as well as milk consumption were significantly associated with positive Lausannevirus serologies $(p=$ 0.0066 and 0.028 , respectively). Coreactivity analyses revealed an association between Criblamydia sequanensis (an
\end{abstract}

amoeba-resisting bacterium present in water environments) and Lausannevirus seropositivity $(p=0.001)$. Conclusions: Lausannevirus seroprevalence is low in asymptomatic Swiss men. However, the association between virus seropositivity and frequent sport practice suggests that this member of the Megavirales may be transmitted by aerosols and/or exposure to specific outdoor environments. Milk intake was also associated with seropositivity. Whether the coreactivity observed for $C$. sequanensis and Lausannevirus reflects a common mode of acquisition or some unexpected cross-reactivity remains to be determined.

(c) 2013 S. Karger AG, Basel

\section{Introduction}

Lausannevirus is a new member of the Marseilleviridae family, which is part of the Megavirales [1]. It was discovered by amoebal coculture in 2005 from a sample collected in the Seine river (Paris, France) [2]. Lausannevirus grows rapidly in amoebal coculture using Acanthamoeba as the cell background, with a 3-log increase in $16 \mathrm{~h}$ and complete amoebal lysis after about $24 \mathrm{~h} \mathrm{[2].}$

The Marseilleviridae family contains two more members: Marseillevirus [3] and Senegalvirus [4]. The latter

\begin{tabular}{ll}
\hline KARGER & $\begin{array}{l}\text { (c) 2013 S. Karger AG, Basel } \\
0300-5526 / 13 / 0566-0430 \$ 38.00 / 0 \quad \text { Karger }\end{array}$ \\
$\begin{array}{l}\text { E-Mail karger@karger.com } \\
\text { www.karger.com/int }\end{array}$ & $\begin{array}{l}\text { This is an Open Access article licensed under the terms of the } \\
\text { Creative Commons Attribution-NonCommercial 3.0 Un- } \\
\text { ported license (CC BY-NC) (www.karger.com/OA-license), } \\
\text { applicable to the online version of the article only. Distribu- } \\
\text { tion permitted for non-commercial purposes only. }\end{array}$
\end{tabular}

Gilbert Greub

Center for Research on Intracellular Bacteria (CRIB)

Institute of Microbiology, University Hospital Center and University of Lausanne

Bugnon 48, CH-1011 Lausanne (Switzerland)

E-Mail gilbert.greub@chuv.ch 
strain was recovered from the stools of an asymptomatic individual in Senegal, demonstrating that humans may be exposed to these large viruses. It is thus important to study the ecology and the possible medical importance of Lausannevirus and other Marseilleviridae in addition to understanding their biology.

The genome of Lausannevirus is $346,754 \mathrm{bp}$ long and contains 450 genes. It exhibits a strong synteny with the 2 distal thirds of the genome of Marseillevirus $[1,2]$. Interestingly, this icosahedral virus has a size of about 200 $\mathrm{nm}$, allowing its observation by optical microscope [2]. This allowed the straightforward development of a microimmunofluorescence assay using as antigen a whole Lausannevirus viral particle. This serological assay was then applied to 517 asymptomatic young adults in order to determine the seroprevalence and ideally identify some specific source of exposure to Lausannevirus.

\section{Methods}

Patients and Statistical Analyses

We took advantage of the availability of sera from previous seroprevalence studies on Chlamydia trachomatis and Chlamydialike organisms $[5,6]$. All Swiss young men who presented at the medical entry examination at the Army recruitment Centre of Lausanne in winter 2006-2007 were enrolled in this study. A questionnaire was filled to collect demographic data, sexual and behavioral risk, and also animal exposure. Sera were analyzed by immunofluorescence (see below), using as antigen Lausannevirus particles grown in amoebae and purified by ultracentrifugation (see below). Statistical analyses were performed using R [7].

\section{Growth of Lausannevirus}

Lausannevirus was grown in Acanthamoeba castellanii ATCC 30010 as described previously [2]. Briefly, we filtered at $5 \mu \mathrm{m}$ a 1 -week infected $A$. castellanii flask grown in peptone yeast-extract glucose at $32^{\circ}$ and we re-infected a new flask with the filtrate. Five days later, the virus was harvested and flask supernatant was centrifuged at 5,000 $\mathrm{g}$ for $15 \mathrm{~min}$. The supernatant was then collected and filtered at $5 \mu \mathrm{m}$ to remove residual amoebal cells. The filtrate was then centrifuged at $35,000 \mathrm{~g}$ for $1 \mathrm{~h}$ and the virus pellet was resuspended in $1 \mathrm{ml}$ of PBS.

\section{Immunofluorescence}

Sera were investigated by microimmunofluorescence as described previously [8], using formaldehyde-inactivated viral particles as antigen. Briefly, sera were screened for Lausannevirus antibodies at a dilution of 1:64 with FluolineH. Mice polyclonal antiLausannevirus antibodies were used as positive control and PBS was used as negative control. IgG and IgM reactivity were tested for sera exhibiting a total Ig titre $\geq 1: 64$, as previously described [9]. IgG and IgM positivity cut-offs were $\geq 1: 32$. Blind lecture of each microimmunofluorescence was performed by two independent observers. A targeted lecture of 11 doubtful samples was performed by a third reader.

Lausannevirus Seroprevalence among Asymptomatic Young Adults
Table 1. Lausannevirus prevalence according to demographic, social and behavioral factors among 517 young Swiss males

\begin{tabular}{|c|c|c|c|}
\hline Characteristics & $\begin{array}{l}\text { Lausannevirus } \\
\text { positive } \\
(\mathrm{n}=13 ; 2.51 \%)\end{array}$ & $\begin{array}{l}\text { Lausannevirus } \\
\text { negative } \\
(\mathrm{n}=504 ; 97.49 \%)\end{array}$ & p value ${ }^{1}$ \\
\hline \multicolumn{4}{|l|}{ Nationality at birth } \\
\hline Swiss & $11(84.62)$ & $424(84.13)$ & 1 \\
\hline Other & $2(15.38)$ & $80(15.87)$ & \\
\hline \multicolumn{4}{|l|}{ Place of residence ${ }^{2}$} \\
\hline$>10,000$ inhabitants & $8(61.54)$ & $209(41.47)$ & 0.26 \\
\hline$<10,000$ inhabitants & $5(38.46)$ & $279(55.36)$ & \\
\hline \multicolumn{4}{|l|}{ Main occupation $^{2}$} \\
\hline Student & $8(61.54)$ & $199(39.48)$ & 0.26 \\
\hline Work & $5(38.46)$ & $269(53.37)$ & \\
\hline \multicolumn{4}{|l|}{ Contact with animals } \\
\hline Animal contact & $5(38.46)$ & $260(51.6)$ & 0.41 \\
\hline No animal contact & $8(61.54)$ & $244(48.41)$ & \\
\hline \multicolumn{4}{|l|}{ Smoking/drugs } \\
\hline Cigarettes & $4(30.77)$ & $242(48.02)$ & 0.26 \\
\hline Cannabis & $3(23.08)$ & $137(27.18)$ & 1.00 \\
\hline Drugs & $0(0)$ & $23(4.56)$ & 1.00 \\
\hline Alcohol $\geq 2 \times /$ week & $10(76.92)$ & $341(67.66)$ & 0.37 \\
\hline \multicolumn{4}{|l|}{ Any reported disease } \\
\hline Asthma & $0(0)$ & $35(6.94)$ & 1.00 \\
\hline \multicolumn{4}{|l|}{ Sport practice $^{2}$} \\
\hline$\geq 3 \times /$ week & $5(38.46)$ & $83(16.46)$ & 0.0066 \\
\hline$\leq 3 \times /$ week & $1(7.69)$ & $235(46.62)$ & \\
\hline \multicolumn{4}{|l|}{ Milk consumption $^{2}$} \\
\hline Milk consumption & $11(84.62)$ & $494(98.01)$ & 0.028 \\
\hline \multirow{2}{*}{\multicolumn{4}{|c|}{ Sexual orientation ${ }^{2}$}} \\
\hline & & & \\
\hline Heterosexual & $8(61.54)$ & $382(75.79)$ & 0.17 \\
\hline Homo-/bisexual & $1(7.69)$ & $8(1.59)$ & \\
\hline \multicolumn{4}{|l|}{ Condom use ${ }^{2}$} \\
\hline Always & $5(38.46)$ & $158(31.34)$ & 0.55 \\
\hline Sometimes & $7(53.84)$ & $313(62.1)$ & \\
\hline
\end{tabular}

Values in parentheses are percentages.

${ }^{1}$ Determined by Fisher's exact $\chi^{2}$ test.

${ }^{2}$ Some patients declined to answer this question and were excluded from statistical analysis.

\section{Results}

According to the first reader, among the 517 volunteers tested, aged from 18 to 26 years, 13 exhibited antibody reactivity against Lausannevirus, corresponding to a Lausannevirus seroprevalence of $2.51 \%$. Among the 13 seropositive patients identified by the first reader, 9 were confirmed by at least one of the additional readers, reducing the seroprevalence rate to $1.74 \%$. Considering all 13 positive patients, demographic, social and behavioral characteristics as well as animal contact are reported in 
Table 2. Coreactivity between Lausannevirus and Chlamydia as well as Chlamydia-related organisms

\begin{tabular}{lllll}
\hline Bacteria & $\begin{array}{l}\text { Bacteria } \\
\text { positive }\end{array}$ & $\begin{array}{l}\text { Lausannevirus } \\
\text { positive } \\
(\mathrm{n}=13 ; 2.51 \%)\end{array}$ & $\begin{array}{l}\text { Lausannevirus } \\
\text { negative } \\
(\mathrm{n}=504 ; 97.49 \%)\end{array}$ & $\mathrm{p}^{\text {value }}{ }^{1}$ \\
\hline Waddlia chondrophila & $167(32.3)$ & $5(38.46)$ & $162(32.14)$ & 0.67 \\
Criblamydia sequanensis & $252(48.74)$ & $9(69.23)$ & $243(48.21)$ & 0.001 \\
Parachlamydia acanthamoebae & $17(3.29)$ & $1(7.69)$ & $16(3.17)$ & 0.37 \\
Protochlamydia naegleriophila & $4(0.77)$ & $1(7.69)$ & $3(0.60)$ & 0.1 \\
Chlamydia trachomatis & $6(1.16)$ & $1(7.69)$ & $5(1.00)$ & 0.14 \\
\hline
\end{tabular}

Values in parentheses are percentages. ${ }^{1}$ Determined by Fisher's exact $\chi^{2}$ test.

table 1. Among the seropositive volunteers, $84.6 \%$ were Swiss, $61.5 \%$ lived in cities with more than 10,000 inhabitants and $61.5 \%$ were students. A total of $84.5 \%$ of participants reported to be sexually active and $60.35 \%$ of them admitted to have had more than two previous partners. However, no correlation was observed between Lausannevirus seropositivity and sexual behavior (table 1). Among the 517 volunteers, 58.79\% had contact with animals but, again, no association has been observed (table 1). Other behavioral risks have also been analyzed, showing no correlation between virus infection and smoking, alcohol intake or drug consumption (table 1). On the contrary, frequent sports practice and milk consumption were associated with Lausannevirus seropositivity ( $\mathrm{p}=0.0066$ and 0.028 , respectively). Analysis on the 9 patients showing anti-Lausannevirus antibodies reported that the correlation between Lausannevirus seropositivity and milk consumption was maintained $(p=0.02)$, while the correlation with a frequent sport activity was no longer statistically significant $(\mathrm{p}=0.06)$.

\section{Discussion}

This first Lausannevirus seroepidemiological study performed among 517 young asymptomatic Swiss adults demonstrated that humans might be exposed to Lausannevirus and/or other related cross-reactive viruses (table 1). The relatively low seroprevalence observed (1.74-2.51\%) may be explained by the characteristics of the target population which is composed exclusively of asymptomatic young Swiss men. Since this is the first study investigating Lausannevirus seroprevalence, no data from others countries or from different target populations are available to draw any comparison.
Further investigations revealed no correlation between seropositivity and sexual behavior or animal contact, excluding sexual and zoonotic exposure to Lausannevirus (table 1). Frequent sports practice has been shown to be strongly associated with seropositivity ( $\mathrm{p}=$ 0.0066). Sportspeople have an active social life, allowing meeting and socializing with many people and sharing the same exercise environments, such as gyms or swimming pools. Also, most of the sports are practiced outdoors (for example in mountains or forests), which may represent another exposure route. Taken together, these observations suggest that humans come into contact with Lausannevirus by exposure to water or soil during sports activities. Milk consumption has also been shown to be associated with Lausannevirus seropositivity $(\mathrm{p}=0.028)$. It is possible that cows shed Lausannevirus particles in their milk; however, this remains to be determined. Since previous studies focused on C. trachomatis and Chlamydia-like prevalence on the same target population $[5,9]$, we investigated a potential coreactivity between these bacterial species and Lausannevirus. Unexpectedly, we observed a strong association between Lausannevirus seropositivity and antibodies directed against Criblamydia sequanensis $(\mathrm{p}=0.001$; table 2$)$. Conversely, we observed no coreactivity between Lausannevirus and Waddlia chondrophila, which has been identified in bovine abortion and which is considered to be a possible zoonotic agent $[6,8]$.

Coreactivity with C. sequanensis may be due to a common mode of exposure because C. sequanensis is a Chlamydia-related bacterium generally associated with water and free-living amoebae, and Lausannevirus has been isolated from water by amoebal coculture. Thus, amoebae might act as a reservoir of Lausannevirus and humans might become infected following exposure to contaminated water, similarly to what is known for Legionella 
[10]. Whether amoebae act as a Trojan horse by increasing the viral infectivity remains to be determined. Nevertheless, resistance to amoebal microbicidal effectors may be associated with resistance to microbicidal effectors of human macrophages [11]. Conversely, the absence of coreactivity with $C$. trachomatis ( $\mathrm{p}>0.05$ ), the most common sexually transmitted bacteria, suggests that Lausannevirus is not sexually transmitted and is congruent with our observed absence of association between seroprevalence and risky sexual behavior. However, due to the limited number of patients exhibiting anti-C. trachomatis antibodies, we were not able to definitely rule out a sexual transmission.

Coreactivity with $C$. sequanensis may also arise as a result of cross-reactivity with a shared epitope. However, this latter hypothesis is unlikely, since Lausannevirus is distantly related to C. sequanensis. BLASTP analysis for small highly conserved peptides between these two microorganisms revealed that only 1 peptide of 10 amino acids in the deoxyuridine $5^{\prime}$-triphosphate nucleotidohydrolase is identical (100\%). Thus, the recognition of a linear epitope is unlikely. However, we are not able to exclude a possible recognition of conformational epitopes. Although the described coreactivity between Lausanne- virus and an amoeba-resisting bacterium suggests a seroconversion following infection by Lausannevirus-containing amoebae, we cannot exclude the possibility that Lausannevirus is able to directly infect humans, without using amoebae as a Trojan horse. In fact, recent studies have demonstrated the presence of viruses of Marseilleviridae and Mimiviridae families in human samples $[1,12]$.

For the future, we suggest expanding the seroprevalence studies to other countries, for example France and Senegal, from where Lausannevirus, Marseillevirus and Senegalvirus have been isolated. Furthermore, the sampling population should be increased to include persons with various infectious diseases of unknown etiology, people of different ages, as well as women, since seroprevalence may be gender dependent. Moreover, it will be interesting to evaluate whether Lausannevirus is circulating in the blood of asymptomatic subjects by using a specific PCR, which exhibits a high sensitivity.

\section{Disclosure Statement}

The authors have no conflict of interest.

\section{References}

1 Colson P, Fancello L, Gimenez G, Armougom F, Desnues C, Fournous G, Yoosuf N, Million M, La Scola B, Raoult D: Evidence of the megavirome in humans. J Clin Virol 2013;57: 191-200.

2 Thomas V, Bertelli C, Collyn F, Casson N, Telenti A, Goesmann A, Croxatto A, Greub G: Lausannevirus, a giant amoebal virus encoding histone doublets. Environ Microbiol 2011;13:1454-1466.

-3 Boyer M, Yutin N, Pagnier I, Barrassi L, Fournous G, Espinosa L, Robert C, Azza S, Sun S, Rossmann MG, Suzan-Monti M, La Scola B, Koonin EV, Raoult D: Giant Marseillevirus highlights the role of amoebae as a melting pot in emergence of chimeric microorganisms. Proc Natl Acad Sci USA 2009;106: 21848-21853.
4 Lagier JC, El Karkouri K, Nguyen TT, Armougom F, Raoult D, Fournier PE: Non-contiguous finished genome sequence and description of Anaerococcus senegalensis sp. nov. Stand Genomic Sci 2012;6:116-125.

5 Baud D, Jaton K, Bertelli C, Kulling JP, Greub G: Low prevalence of Chlamydia trachomatis infection in asymptomatic young Swiss men. BMC Infect Dis 2008;8:45.

6 Baud D, Goy G, Osterheld MC, Borel N, Vial Y, Pospischil A, Greub G: Waddlia chondrophila: from bovine abortion to human miscarriage. Clin Infect Dis 2011;52:14691471.

7 Team RDC: R: A Language and Environment for Statistical Computing: Reference Index. R Foundation for Statistical Computing, 2008.

-8 Baud D, Thomas V, Arafa A, Regan L, Greub G: Waddlia chondrophila, a potential agent of human fetal death. Emerg Infect Dis 2007;13: 1239-1243.
9 Baud D, Kebbi C, Kuelling JP, Greub G: Seroprevalence of different Chlamydia-like organisms in an asymptomatic population. Clin Microbiol Infect 2009;15:213-215.

10 Borella P, Montagna MT, Romano-Spica V, Stampi S, Stancanelli G, Triassi M, Neglia R, Marchesi I, Fantuzzi G, Tatò D, Napoli C, Quaranta G, Laurenti P, Leoni E, De Luca G, Ossi C, Moro M, Ribera D’Alcalà G: Legionella infection risk from domestic hot water. Emerg Infect Dis 2004;10:457-464.

11 Greub G, Raoult D: Microorganisms resistant to free-living amoebae. Clin Microbiol 2004; 17:413-433.

12 Saadi H, Pagnier I, Colson P, Cherif J, Beji M, Azza S, Armstrong N, Robert C, Fournous G, La Scola B, Raoult D: First isolation of Mimivirus in a patient with pneumonia. Clin Infect Dis 2013;57:e127-e134. 